\title{
EchoGéo
}

29 | 2014

The Political Ecology of Conservation and

Development Territories

\section{Regulation by Territorialization: The Political Ecology of Conservation \& Development Territories Introduction}

\section{Thomas J. Bassett and Denis Gautier}

\section{(2) OpenEdition Journals}

\section{Electronic version}

URL: https://journals.openedition.org/echogeo/14038

DOI: 10.4000/echogeo.14038

ISSN: 1963-1197

\section{Publisher}

Pôle de recherche pour l'organisation et la diffusion de l'information géographique (CNRS UMR 8586)

\section{Electronic reference}

Thomas J. Bassett and Denis Gautier, "Regulation by Territorialization: The Political Ecology of Conservation \& Development Territories", EchoGéo [Online], 29 | 2014, Online since 18 November 2014, connection on 31 July 2021. URL: http://journals.openedition.org/echogeo/14038; DOI: https:// doi.org/10.4000/echogeo.14038

\section{This text was automatically generated on 31 July 2021.}

EchoGéo est mis à disposition selon les termes de la licence Creative Commons Attribution - Pas d'Utilisation Commerciale - Pas de Modification 4.0 International (CC BY-NC-ND) 


\title{
Regulation by Territorialization: The Political Ecology of Conservation \& Development Territories
}

\author{
Introduction
}

Thomas J. Bassett and Denis Gautier

\section{Introduction}

1 Under the banners of environmental conservation, food security, and sustainable development, a diverse group of public and private actors is busily dividing the global South into conservation and development territories at a variety of scales. Multiple goals and processes drive these spatial strategies to reconfigure resource access, control, and management. The production of territory to regulate populations and resources has a long tradition (Elden, 2013; Sack, 1986; Scott, 1998). National Parks, biosphere reserves, and export-processing zones are well-known state territorial practices for governing conservation and development. Contemporary territorial projects build upon and rework these past models and practices (Neumann, 2004; Wilshusen et al., 2002). What is novel about the current period is the diversity of actors, institutions, and spatial practices involved in dividing the lands and waters of the world (Fairhead et al, 2012). Public-private partnerships are creating agricultural growth corridors in Tanzania and Mozambique. Governments in Latin America and South Asia are working with international organizations, environmental NGOs, and financial institutions to divide tropical forests into concessions for carbon sequestration, biodiversity conservation, and carbon offset schemes. In West Africa, governments are sub-dividing the countryside into zones in which agribusiness firms monopolize input and output markets. And in many places territorial approaches (e.g. the "terroir") and geo-spatial technologies are being used in the privatization of 
common lands (Bassett, Blanc-Pamard and Boutrais, 2007). These new spatial practices, concepts, and interventions can be added to a long list of previously demarcated conservation and development territories: buffer zones and wildlife corridors in Integrated Conservation and Development Programs, international peace parks and transfrontier reserves, debt-for-nature swaps, and extractive reserves. Market environmentalism, science-policy discourses, and land privatization are major driving forces behind these new enclosures (Fairhead et al, 2012).

2 The concept of "territory" and the related terms of "territoriality" and "territorialization" are relatively understudied by human geographers (Elden, 2010). It is thus important to define these basic terms in order to elucidate the political ecological approach to conservation and development territories, the focus of this special issue. Territory is a socially constructed space that is characterized by its historical, cultural, technical, and political-economic origins (Elden, 2010). Territories are recognizable by their "discrete, distinctive, bounded, measurable, communicable spaces that are deliberately created in an effort to achieve certain social goals" (Murphy, 2012, p. 164). Territory is both a relation and outcome of the process of territoriality, which Robert Sack defines an "attempt by an individual or group to affect, influence, or control people, phenomena, and relationships by delimiting and asserting control over a geographic area (Sack, 1986, p.19). As a strategy, territoriality is inextricably linked to social relationships that structure the aspirations and possibilities for producing territories. This relational approach to territoriality, when combined with Sack's conceptualization, enriches the notion of territoriality as a strategy that produces social relations at the same time that it is produced by them (Murphy, 2012, p. 169).

3 Territorialization refers to specific territorial projects in which various actors deploy territorial strategies (territoriality) to produce bounded and controlled spaces (territory) to achieve certain effects. A common goal of territorialization is to govern people and resources located within and around the territory (Scott, 1998). Control can be heavy handed as in the forced eviction of people from ancestral lands. But "coercive conservation" is just one of the many modalities of territorialization (Peluso, 1993). Territorialization can also work indirectly through prescribing and proscribing certain activities that affect resource access, control, and management. This socio-spatial reconfiguration is typically achieved by establishing new laws, regulations, and authorities that alter human-environmental relationships. The process is also characterized by the deployment of environment-development discourses. These discourses often portray state actors as enlightened stewards of natural resources who are capable of addressing environment and development problems in a responsible and sustainable manner. Resource users, on the other hand, are typically depicted by state actors as destructive, inefficient, and ignorant actors who need to be reorganized and disciplined via new socio-spatial arrangements engineered by the state. New subjectivities and collaborations as well as resistance may emerge within these refashioned environment-development geographies.

4 This special issue of ÉchoGéo contributes to the territorialization literature by critically engaging with the notion of "regulation by territorialization," a core theoretical tenet of the literature. The authors complicate this state-centric and functionalist notion in which resource access, control, and management invariably shifts from the poor to the powerful in the process of territorialization. They do so by analyzing the production of 
conservation and development territories through the lens of political ecology. Political ecology is an interdisciplinary approach to the study of natural resource access, control, and management that emphasizes the interplay of multiple actors (human and nonhuman) at multiple scales over time with particular attention to the influence of political and biophysical relations on human-environmental change dynamics. Political ecological perspectives draw on a diversity of social and ecological theories to analyze the processes shaping human-environmental relationships. In contrasting urban and rural settings, the five papers take a relational approach to their cases studies of territorialization that demonstrate the polycentric origins and contested boundaries of conservation and development territories. The case studies and the authors' analytical frameworks illustrate what we call here a political ecology of territorialization. The remainder of this introduction highlights the main elements of this innovative approach to territorialization with emphasis on the theoretical relevance of the authors' findings for the key notion of regulation by territorialization.

\section{Territorialization as a polycentric process}

In contrast to the state-centric focus of the territorialization literature, the case studies collected here illustrate that the production of territories springs from multiple sources and locations. In her discourse analysis of conservation policies in Benin, Fanny Pochet shows how international environmental NGOs have become key players in the making of conservation territories. Whereas the dominant conservation discourse between 1992 and 2002 promoted the participation of communities neighboring protected areas in conservation programs, international NGOs argued for a "back to the barriers" model that led to the unprecedented extension of protected areas to $23 \%$ of Benin's national territory.

Nicole List shows how land insecure farmers in Pikine, Senegal, adopted a territorial strategy and built "territorial alliances" to maintain control over their urban farmland that agribusiness firms and real estate companies sought to convert to other uses. Pikine's urban famers in one location (Pikine North) created a small-scale conservation and development territory by buying up farmland, creating a powerful farmer association, and allying themselves with certain local and central government officials. The success of this "territorial alliance" to block horticultural firms and housing developers from encroaching on their lands demonstrates that the motivations for territory making can come from below as well as from above.

7 Sarah Audouin and Alexis Gonin present a similar case of bottom up territiorialization in southwestern Burkina Faso where customary land authorities direct immigrant farmers to establish cashew plantations in a specific area. The aggregation of plantations is designed to attract Asiatic traders to this development territory. Its deliberate construction is to the detriment of mobile pastoralists whose access to rangelands is reduced by the massive expansion of cashew trees in the landscape.

\section{Multiple motivations for territoralization}

8 The prevailing view that states adopt territorial strategies to control people and resources reduces the multiple objectives of the state to just one goal. The contribution of Delphine Ayerbe demonstrates that local and central governments are keen to 
restrict access to reforested lands at the edge of Addis Ababa for a variety of reasons. To be sure, the municipal agency and parastatal corporation that manage the eucalyptus plantations do limit local access to these managed forests. However, the state does allow local women to collect fallen branches and dead wood to sell in informal firewood markets in the burgeoning city. This controlled access serves not only local energy needs but also the forest management goal of reducing fire and disease hazards in the plantation. Forest managers also sell wood to carpenters and construction companies for housing development and furniture markets. Delphine Ayerbe argues that this state-controlled wood market works to control prices of wood coming into Addis from outlying provinces to make it affordable to city residents. The plantations are also valued as a wood supply reserve for future development needs like the planned paper mill. In addition, the plantations' urban peripheral location is valued by the state as a future location of potential upscale housing development. A final objective of the conservation/development territory is to serve as a model of natural resource management. The state considers itself to be a wise steward of the country's natural resources and that its practices should be emulated by other Ethiopian government agencies. These multiple goals of eucalyptus plantations in Addis Ababa serve to enlarge the rather narrow view that the goal of territorialization is mainly to regulate resource access, control, and management.

\section{The politics of territorialization}

9 The politics of territory making has always been marked by conflict and violence as the state encounters pre-existing resource claimants who defend their legitimate rights to resources. The case studies assembled here illustrate the stakes and ensuing struggles over resource access and control in the process of territorialization. In the case of Benin, the discourse analysis of Fanny Pochet reveals historical shifts in conservation strategies. Her paper shows that conservation discourses have changed from colonial era "fortress conservation" to "community-based conservation" in the context of state's inability to control conservation territories. More recently a "back to the barriers" discourse associated with international environmental NGOs has superseded the community participatory approach. Despite the discursive shifts, a recurring theme in all conservation policies has been the restriction of people's access to resources. These restrictions range from forced evictions and the criminalization of indigenous resource management activities such as hunting to deciding who can participate in the making of conservation territories. The conservation policies and territories have invariably entailed conflict between local resource users, the state, and international environmental organizations.

10 In their effort to wrestle control over the land managed by Pikine's urban farmers to build a housing project, local and central government authorities and a housing developer sent a bulldozer and police force to expropriate land from farmers who resisted their demands to sell their farms. These coercive measures combined with a divide and rule strategy led to land expropriation in Pikine West. This strategy failed in Pikine North where farmers battled the police and stopped the bulldozer in its tracks. Nicole List argues that the victory of Pikine North farmers in defending their land from urban development was due to a strong "territorial alliance" that brought together farmer organizations, international and local NGOs, government bureaucrats, and 
traditional authorities. She argues that multi-scale strategic alliances are increasingly common in the context of political decentralization. These alliances are replacing past forms of urban governance when central government authorities wielded the most power. In the context of these shifting bases of power, explosive urbanization, and land speculation, Nicole List argues that the politics of territorialization are being driven by competing territorial alliances, which are themselves evolving as the contexts and stakes change.

\section{Differentiated resource claimants and territories}

11 The image of a monolithic state designing territorial schemes at the expense of a undifferentiated subject population is confounded by the territorial alliances that characterize the struggles over farmland described by Nicole List in urban Senegal and Sarah Audouin and Alexis Gonin in Burkina Faso. The state is fragmented into local, district, and central government offices whose members participate in competing alliances. Elected officials take different positions than government bureaucrats in land management agencies who act according to a different set of incentives and rewards. This institutional diversity at the government level is matched by the diversity of actors and logics among resource users at the landscape scale. Some urban farmers and farm association leaders sell out to developers while others stand their ground and maintain control of their farms.

Differences among resource users, especially their unequal rights to resources, stand out in the cashew growing areas of southern Burkina Faso. The principle participants in the bottom up expansion of cashew orchards discussed by Sarah Audouin and Alexis Gonin are largely autochthonous peoples who possess the right to plant perennial crops. Immigrant farmers are generally restricted to growing annual crops. But the situation is fluid, especially in areas of low population density where power relations and the ability of wealthy immigrants to purchase land allows some groups to plant cashew orchards on a relatively large scale with the encouragement of particular land authorities. In the table documenting the winners and losers of the cashew boom, pastoralists appear to be the biggest losers. As fallow fields prized by livestock producers for their high quality pasture are converted to cashew orchards, pastoralist access to rangelands is significantly reduced. Farmer-herder conflicts linked to cattle grazing in unfenced orchards forces pastoralists to move on with their herds to areas where cashew orchards are less common. In summary, the processes of territorialization, whether driven from above or from below, play out in a terrain of social differentiation that results in landscapes of opportunity for some and impoverishment for others.

\section{Conclusion}

The papers in this special issue examine the political ecological dynamics of territorialization in contrasting settings. The authors emphasize the social and political processes that produce new socio-spatial configurations of resource access, control, and management. In contrast to this social relational approach, ecological processes receive comparatively little attention. A more balanced perspective might offer additional insights into the dominant conception of territoriality as "a bounded, 
controllable space with clearly demarcated edges or boundaries that serves to advance particular social ends" (Murphy, 2012, p. 163). Scholars who have seriously engaged with the ecological processes operating in conservation and development territories have observed a spatial mismatch between the limits of such territories and ecological dynamics (Turner, 1999; Zimmerer, 2000). These findings suggest that greater attention to ecological relations, particularly the influence of non-human agency in natural resource management, could lead to more nuanced understandings of the limits of regulation by territorialization.

The contribution of the papers to the territorialization literature is their detailed social relational analysis of the making of conservation and development territories. The collective contribution is four-fold. First, the case studies reveal that territorial strategies emanate from a variety of social locations and aspirations. Smallholder farmers are just as likely to engage in territorial practices as state agencies. Second, the motivations promoting territorialization are as diverse as the actors promoting them. Given the coalition of actors involved in territorial projects, it is unlikely that just one motivation unites them. Third, who ultimately succeeds in the contested process of territorialization and where they are successful depends on power relations under shifting political, economic, and geographical conditions. Power may reside in centralized state authorities or in "territorial alliances" composed of actors located in a diversity of social institutional, and geographic locations. Finally, the territorial projects featured in the five case studies reveal populations and institutions that are far from monolithic. Socially differentiated resource users do not speak with one voice. Nor do government officials whose interests and alliances vary by their institutional commitments. Not surprisingly, there are winners and losers in all territorial projects, which underscores the importance of social relational approaches to the study of territorializtion.

\section{BIBLIOGRAPHY}

Bassett T., Blanc-Pamard C., Bourtrais J. 2007. Constructing locality: the terroir approach in West Africa. Africa, 77(1), p. 104-29.

Elden S. 2010. Land, terrain, territory. Progress in Human Geography, 34(6), p. 799-817.

Elden S. 2013. The Birth of Territory. Chicago: University of Chicago Press.

Fairhead J., Leach M., Scoones I., 2012. Green Grabbing: A new appropriation of nature? Journal of Peasant Studies, 39(2), p. 237-261.

Murphy A. 2012. Entente territorial: Sack and Raffestin on territoriality. Environment and Planning D: Society and Space, 30, p. 159-172.

Neumann R., 1998. Imposing Wilderness: Struggles Over Livelihood and Nature Preservation in Africa. University of California Press, Berkeley, CA. 
Neumann R. 2004. Nature-state-territory: Toward a critical theorization of conservation enclosures. In R. Peet and M. Watts (eds.), Liberation Ecologies: Environment, development, social movements, ( $2^{\text {nd }}$ edition), New York: Routledge, p. 195-217.

Peluso N., 1993. Coercing Conservation? The politics of state resource control. Global Environmental Change, 3(2), p. 199-217.

Peluso N., Lund C., 2011. New frontiers of land control: Introduction. Journal of Peasant Studies, 38(4), p. 667-681.

Sack R., 1986. Human territoriality. Its theory and history. Cambridge: Cambridge University Press.

Schroeder R., 1999. Geographies of environmental intervention in Africa. PHG, 23(3), p. 359-378.

Scott J., 1998. Seeing Like a State: How Certain Schemes to Improve the Human Condition Have Failed. New Haven, CT, Yale University Press.

Turner M.D., 1999. Conflict, environmental change, and social institutions in dryland Africa: Limitations of the community resource management approach. Society and Natural Resources, 12, p. 643-657.

Wilshusen P.R., Brechin S., Fortwangler C., West P., 2002. Reinventing a squarewheel: critique of a resurgent protection paradigm in international biodiversity conservation. Society and Natural Resources, 15, p. 17-40.

Zimmerer K., 2000. The reworking of conservation geographies: Nonequilibrium landscapes and nature-society hybrids. Annals of the Association of American Geographers, 90(2), p. 356-369.

\section{AUTHORS}

\section{THOMAS J. BASSETT}

Thomas J. Bassett, bassett@illinois.edu, is Professor of Geography and GIS, Director, LAS Global Studies, University of Illinois at Urbana-Champaign.He published:

- Bassett T., 2014. Capturing the margins: World market prices and cotton farmer incomes in West Africa. World Development, 59, p. 408-421.

- Bassett T., Fogelman C., 2013. Déjà vu or something new? The adaptation concept in the climate change literature. Geoforum, 48, p. 42-53.

- Beymer-Farris B., Bassett T., 2012. The REDD Menace: Resurgent protectionism in Tanzania's mangrove forests. Global Environmental Change, 22, p. 332-341.

\section{DENIS GAUTIER}

Denis Gautier, denis.gautier@cirad.fr, est chercheur au CIRAD, département Environnements et Sociétés, Unité de Recherche "Biens et Services des Ecosystèmes Forestiers tropicaux". Il est actuellement seconded scientist au CIFOR (Center for International Forestry Research), basé au Burkina Faso. Il a publié sur cette question :

- Gautier D., 2011. De la gestion centralisée des savanes d'Afrique de l'Ouest aux territoires de conservation et de développement dans un contexte de globalisation environnementale. Dossier d'Habilitation à Diriger des Recherches, Université de Paris 1 Panthéon La Sorbonne, Ecole doctorale de géographie de Paris.

- Gautier D., Benjaminsen (T.A.) (eds.), 2012. Environnement, Discours et Pouvoir. L'approche Political Ecology. Quae, Versailles, $261 \mathrm{p}$. 
- Gautier D., Haudidier (B.), Gazull (L.), 2011. Woodcutting and territorial claims in Mali. Geoforum, 42 (1), p. 28-39. 